\title{
GEOELECTRICAL EXPLORATION FOR GROUNDWATER IN CRYSTALLINE BASEMENT ROCKS OF GBONGUDU COMMUNITY, IBADAN, SOUTHWESTERN NIGERIA
}

\author{
M. A. OLADUNJOYE, I. A. KORODE AND A. ADEFEHINTI
}

(Received 4 September 2018; Revision Accepted 26 October 2018)

\begin{abstract}
Gbongudu community, Ibadan underlain by crystalline rocks of Basement Complex of Southwestern Nigeria has need for alternative water supply due to inadequacies of surface water supply and common occurrences of low yield or dry boreholes coupled with rapid development within the community. Geophysical investigation involving electrical resistivity was carried out with the aim of evaluating the groundwater potential of the community. Thirty-three (33) Vertical Electrical Soundings were acquired across the community adopting Schlumberger electrode configuration with current electrode separation $(A B)$ varying from 2 to $200 \mathrm{~m}$. The acquired field data were interpreted using partial curve matching with suitable auxiliary chart and "RESIST" resistivity sounding interpretation software was also used for iteration.

The results revealed two to five geo-electric layers, namely, topsoil, clayey soil, lateritic clay, weathered layer, fractured unit and fresh basement. The weathered and the fractured units form the aquiferous zones in the area investigated. Thematic maps of geoelectric and Dar-Zarrouk parameters produced from the interpreted VES data are aquifer unit (weathered layer) thickness map, aquifer unit (weathered layer) resistivity map, overburden thickness map, basement resistivity map, basement topography map, reflection coefficient map, total longitudinal conductance map, total transverse resistance map and electrical anisotropy (coefficient of anisotropy) map. The thematic maps were combined to form a single component which gives the groundwater potential map of the study area. The groundwater potential map was used to classify the study area into poor, low and good aquifer potential zones. The study reveals that the weathered and fractured zone that occur in the southeastern part of the study area constitute the water bearing zone which can be regarded as good groundwater potential. This study has provided evidence on the hydrogeologic framework and subsurface nature of main aquifer units in the area.
\end{abstract}

KEY WORDS: Groundwater exploration, RESIST, Dar-Zarrouk parameters, Electrical anisotropy, Borehole drilling.

\section{INTRODUCTION}

Groundwater is one of the most precious natural resources which determines the health and well-being of people living in any environment. Groundwater is referred to as the waters found under the surface of ground (Bear and Verruijt, 1987). It is very important because it is the source of water for some communities that they depend on it for domestic, agricultural, and industrial uses. Naturally, groundwater is being replenished by rain which infiltrate the soil or through secondary pores of the subsurface rocks (Nampak et al., 2014). Therefore, the occurrence and distribution of groundwater in an area can be influenced by; climatic condition, geology, the structural features present in the subsurface rock, geomorphological features, land use type and their interplay with the hydrological features (Edetet al., 1998, Jaturonet al., 2014, Kumar et al., 2007). FAO, (2003) affirmed that globally $26 \%$ of the renewable fresh water resources is from groundwater. The factors that influenced the occurrence of groundwater vary from one location to another. In the study of groundwater resources, different factors have been adopted as indices. In hard rock terrain, the observed lithologic unit comprises of weathered layer, weathered/ fractured unit and fresh basement (Omorinola, 1984). The type of geologic materials contained in the selithologies determines the capacity of their permeability and porosity (Ojo and Olorunfemi, 1990). Fractured basement will be more porous and permeable than weathered layers that consist of clay.

Geophysical methods have solved numerous exploration problems because it is rapid and can cover expanse of land in limited time and also can penetrate subsurface to a greater depth. It has been a very useful tool in mapping subsurface, estimating reserves in mineral resources exploration and monitoring pollution. The geophysical method that mostly used for

M. A. Oladunjoye, Department of Geology, University of Ibadan, Ibadan. Nigeria

I. A. Korode, Department of Geology, University of Ibadan, Ibadan. Nigeria

A. Adefehinti, Department of Geology, University of Ibadan, Ibadan. Nigeria 
groundwater exploration is the electrical resistivity method.

Generally, materials be it natural or artificial can resist the flow of electric current. Consequently, it is possible to identify good groundwater potential zones based on the resistance offered by subsurface layers. Factors such as mineral content, texture, moisture content, salinity, fissures and fractures of geological formation have vital influence on the electrical resistivity of any formation. Secondary porosity such as weathered zone, fractures and joints has greater influence on the variation of resistivity value of rocks.

Gbongudu community in Ibadan which is situated within a hard rock terrain and having undulating topography however get adequate rainfall but still suffers from water scarcity for domestic and industrial purposes due to limited nature of aquifers (insufficient weathered and fractured zones). The development and urbanization of the community has been limited due to short supply of water. The present study attempted to map the groundwater potential zones within community using vertical electrical sounding (VES). From the interpreted result, geoelectric parameters such as weathered layer thickness, weathered layer resistivity, basement resistivity, basement topography and basement reflection coefficient were determine and also the DarZarrouk parameters were estimated from the result and their thematic maps generated which were integrated to determine and characterize the groundwater potential zones of the area. The outcome of this research will serve as guide for future borehole development within the community.

\section{Study location and General geology}

The study area covers the entire Gbongudu community, Ibadan in the Southwestern part of Nigeria. It is found within the geographic location of latitude $7^{\circ} 27^{\prime} 18^{\prime \prime}$ and $7^{\circ} 27^{\prime} 50^{\prime \prime}$ North and longitude $3^{\circ} 57^{\prime} 45^{\prime \prime}$ and 358'22" East (Indicate the area extent in $\mathrm{KM}^{2}$ ) (Fig. 1). The topography of the study location is characterized by rugged terrain which slopes from the northern to the southern part with the elevation of the area varying from $210 \mathrm{~m}$ to $265 \mathrm{~m}$. The climate of the area is typical of the tropical rainforest belt of Nigeria with two prominent seasons; the wet and dry seasons. The wet season span between April and October while the dry season commences from November to March. Highest rainfall is usually recorded between June and September while dry season is at peak between December and February. Owoyemi, (1996)observed the mean annual rainfall across the area to be $1333.2 \mathrm{~mm}$ with average annual temperature of approximately $26.5^{\circ}$ and relative humidity of about $76 \%$. Between June and September, evaporation is usually at minimum rate due to heavy rainfall thereby encouraging infiltration to water table.

Geologically, the area is underlain by part of crystalline Precambrian Basement complex rocks of Southwestern, Nigeria (Oyinloye, 2011). The rocks underlying this area are; the undifferentiated gneiss which is made up of migmatite gneiss, banded gneiss and quartzites and pegmatite which intrude the undifferentiated gneiss (Fig. 2). Alternate band of light and dark minerals that aligned in a preferred orientation characterized the gneissic rock. Various structures were observed on the rock surface which include gneissosity, micro folds, joints and minor fractures. Generally, the rock is oriented approximately in $\mathrm{N}-\mathrm{S}$ direction while the structures on the rock run parallel and perpendicular to the general strike direction of the rock.

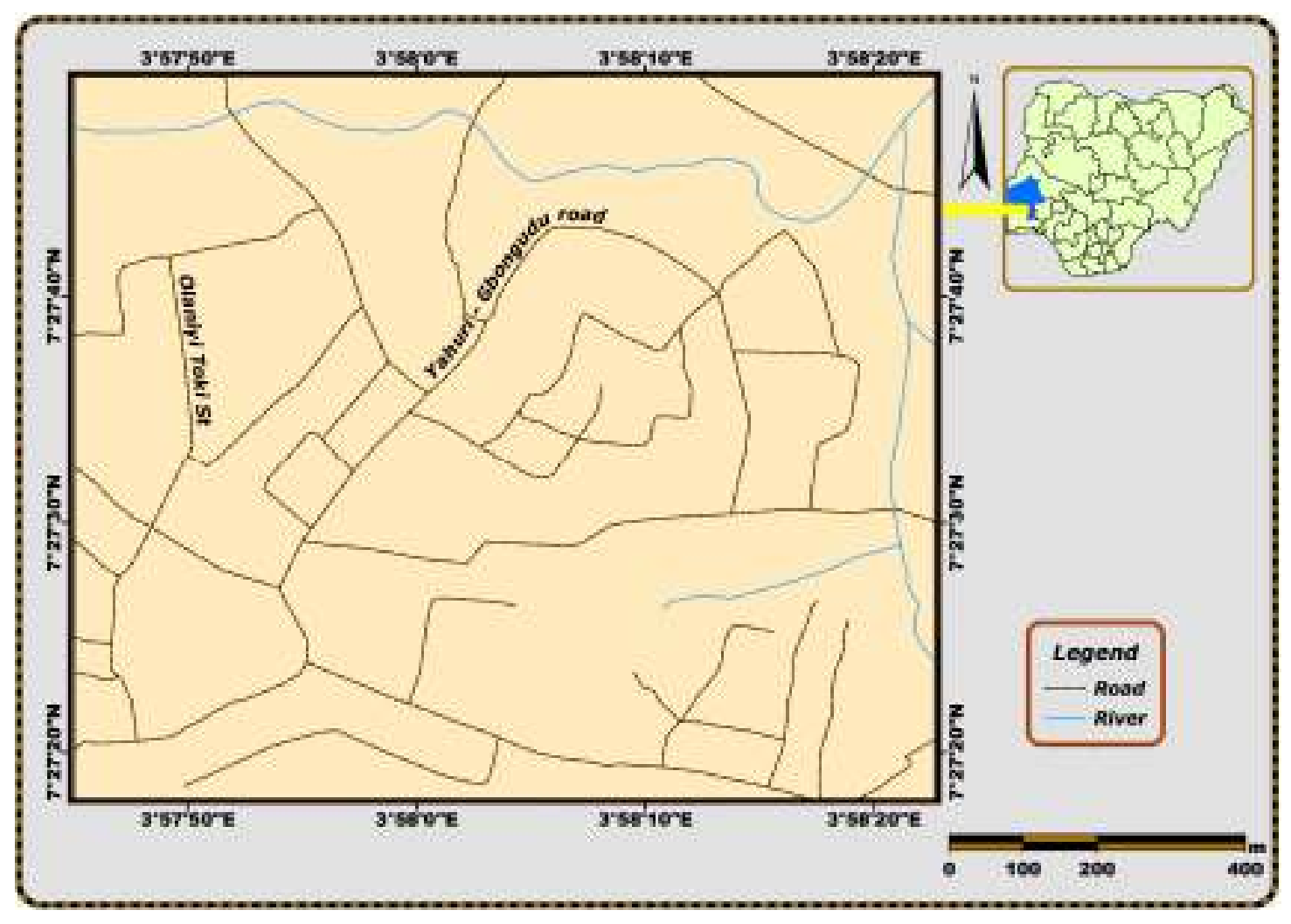

Figure 1: Location, accessibility and drainage map of Gbongudu community, Ibadan 


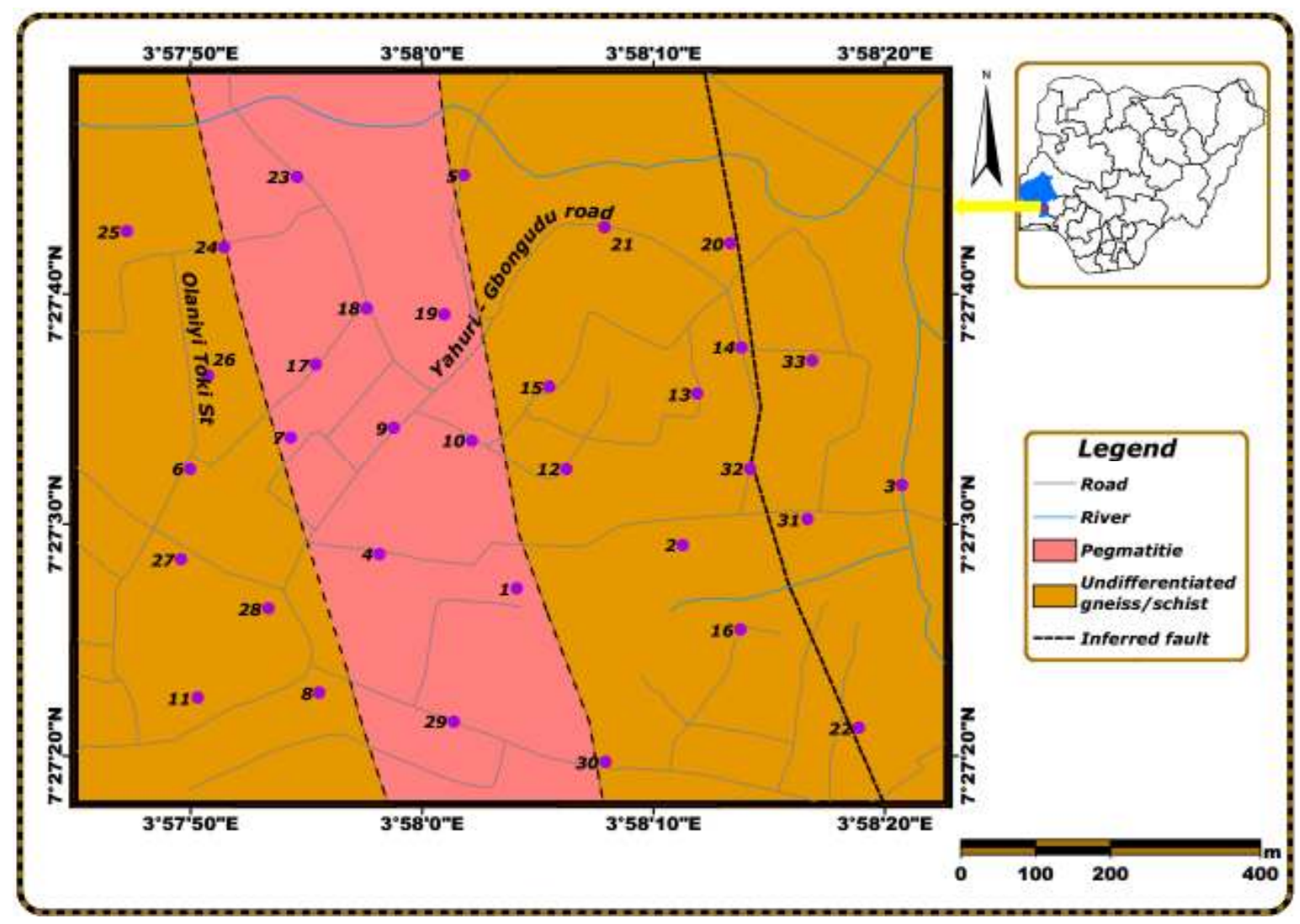

Figure 2: Geological map of Gbongudu community, Ibadan. (Source: NGSA, 2009)

\section{Materials and method}

Electrical resistivity method is generally carried out with two pairs of electrode, the current and the potential electrodes. Electric current is applied between a pair of outer electrodes (current electrodes) and apparent potential difference is passed across the pair of inner electrodes (potential electrodes) and the resultant electrical resistance is then measured. In homogenous ground, the depth of electric current penetration is proportional to the current electrode spacing. Information about the subsurface lithology can be realized from varying the electrode separation (Koefoed, 1979). There are several electrode configurations in electrical resistivity method but the three most commonly used are Wenner, Schlumberger and dipoledipole. For this study, Schlumberger electrode configuration was adopted and vertical electrical sounding (VES) technique was employed for data acquisition. The four electrodes were arranged collinearly, while the distance between the inner electrodes was kept constant, the distance between the outer electrodes were varied for each measurement.

Campus Tigre resistivity meter was used to acquire the VES data with half electrode spacing $(A B / 2)$ ranging between 1 and $100 \mathrm{~m}$. Thirty three (33) VES were spatially acquired (Fig. 3) across the area investigated with observed error less than $1 \%$.

The data were processed manually by plotting it on loglog graph so as to accommodate large variation in resistivity data and the half electrode spacing on the same graph. The data were partially curved matched
Mooney, (1966)with the aid of two-layer master curves and appropriate auxiliary charts as the first stage of preliminary investigation. The final stage of the interpretation was done with "RESIST" software where the model derived from the preliminary interpretation was inputted in the inversion algorithm. From the final model derived from the software, geoelectric parameters which comprises; overburden thickness, weathered basement resistivity, weathered basement thickness, basement rock topography, basement rock resistivity, resistivity contrast and reflection coefficient were acquired. Thematic map for each geoelectric parameter was generated and then integrated which now give the groundwater potential map of the area. The basement rock topography was obtained by subtracting the overburden thickness of each VES point from elevation of the same point. The reflection coefficient was obtained by formula proposed by Olayinka, (1996). The reflection coefficient shows the degree of freshness of the rock at the bedrock interface and can be defined as: $R_{c}=\frac{\rho_{n}-\rho_{(n-1)}}{\rho_{n}+\rho_{(n-1)}}$

Where $\rho_{n}$ is the resistivity of the $\mathrm{n}^{\text {th }}$ layer and $\rho_{(n-1)}$ is the resistivity of layer overlying the $\mathrm{n}^{\text {th }}$ layer.

In interpreting and understanding geoelectrical model for layered earth, certain parameters are fundamental and important. Combination of different thickness and resistivity for each layer in the model are related to these parameters (Singh, 2005). Dar-Zarrouk parameters introduce by Maillet, (1947) plays crucial role in geoelectrical resistivity soundings. In computing the distribution of surface potential for set of $n$ horizontal. 
homogenous and isotropic layers of resistivity $\left(\rho_{\mathrm{i}}\right)$ and thickness $\left(h_{i}\right)$, the longitudinal unit conductance $S$ and the transverse unit resistance $T$ are defined by

$S=\sum_{i=1}^{n} h_{i} / \rho_{i}$ and $T=\sum_{i=1}^{n} h_{i} \cdot \rho_{i}$

While the average longitudinal resistivity $\rho_{L}$, Average transverse resistivity $\rho_{t}$ and electrical anisotropy $\lambda$ are defined by

$\rho_{L}=H / S, \quad$ Where $H=\sum_{i=1}^{n} h_{i}$

$\rho_{t}=T / H$

$\lambda=\frac{\sqrt{S \times T}}{H}=\sqrt{\frac{\rho_{t}}{\rho_{L}}}$
The parameters stated above were determined to the top of the basement rocks in this investigated area. Kriging interpolation method was used to generate contour maps for the geolectric and Dar-Zarrouk parameters. The geolectric and Dar-Zarrouk parameters were integrated using the ranking of groundwater potential as functions of the aquifer resistivity (Wright, 1992), weathered layer thickness, basement resistivity, reflection coefficient (Olayinkaet al., 1997 and Oyedele and Olayinka, 2012) and longitudinal conductance (Oladapoet al., 2004 and Abiolaet al., 2009) to produce groundwater potential map of the study area.

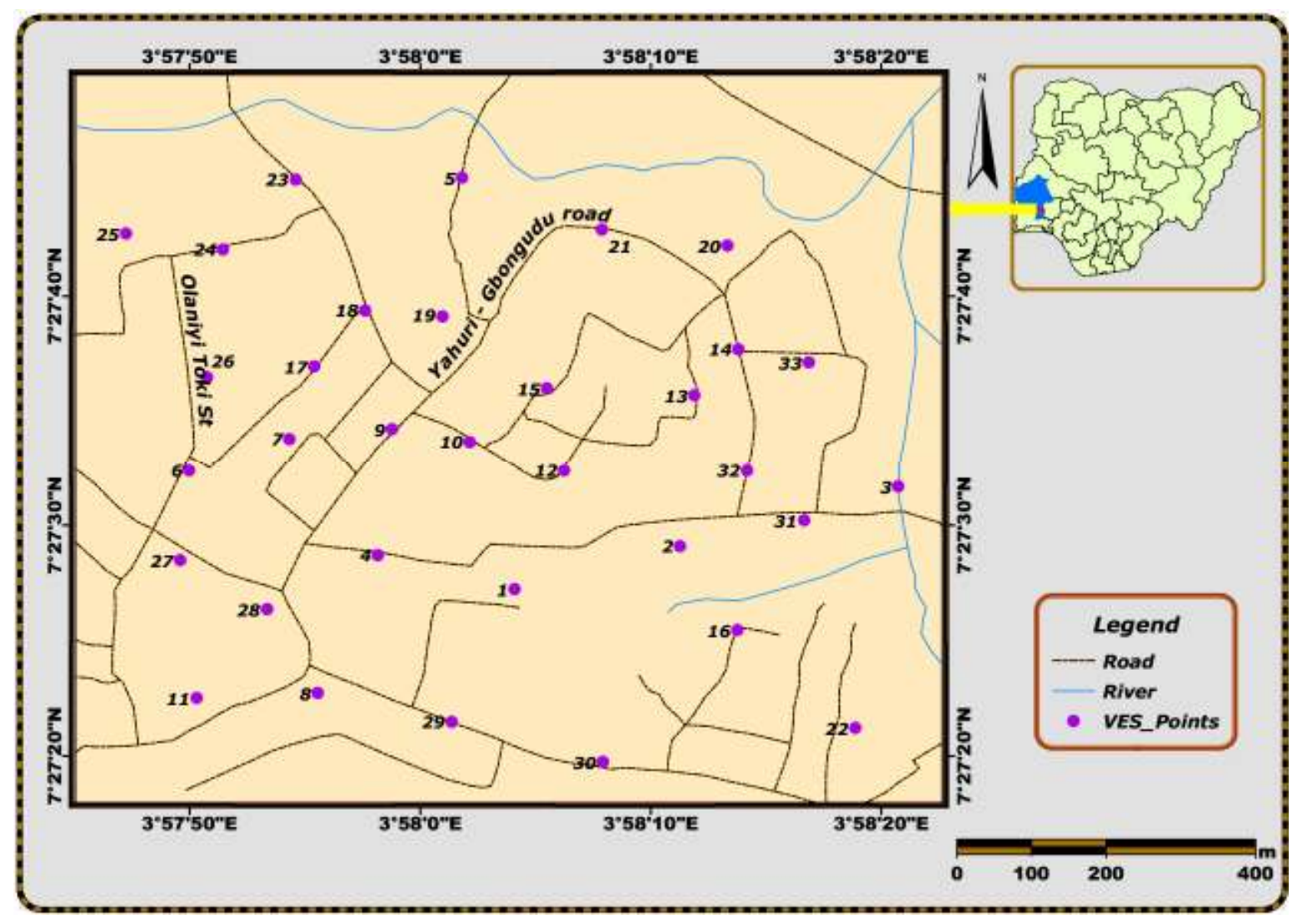

Figure 3: Location map of Gbongudu community, Ibadan showing spatial distribution of the VES points

\section{Interpretation and Result Discussion}

Thirty-three (33) vertical electrical sounding were acquired within the investigated area (Fig. 3).Four representative sample of the curve types found within the study area are shown in figure 4 . The sounding curves obtained from this area ranges from 2 to 5 layers with $\mathrm{H}$ curve type dominating. The summary of the VES interpretation is given in table 1 . The geoelectric layers deduced from the resistivity data are topsoil, clay soil, lateritic clay, weathered layer, fractured unit and fresh basement. Estimated geoelectric parameters are overburden thickness, aquifer unit (weathered basement) resistivity, aquifer unit (weathered basement) thickness, basement resistivity, basement topography, resistivity contrast, reflection coefficient and Dar-Zarrouk parameters.

\section{Geoelectrical Resistivity Parameters}

Varied sounding curves were obtained from the study area. The curve types obtained from this investigation are typical of basement curves which are $\mathrm{A}, \mathrm{H}, \mathrm{KH}$ and $\mathrm{HKH}$. The summary VES interpretation is given in table 1. 

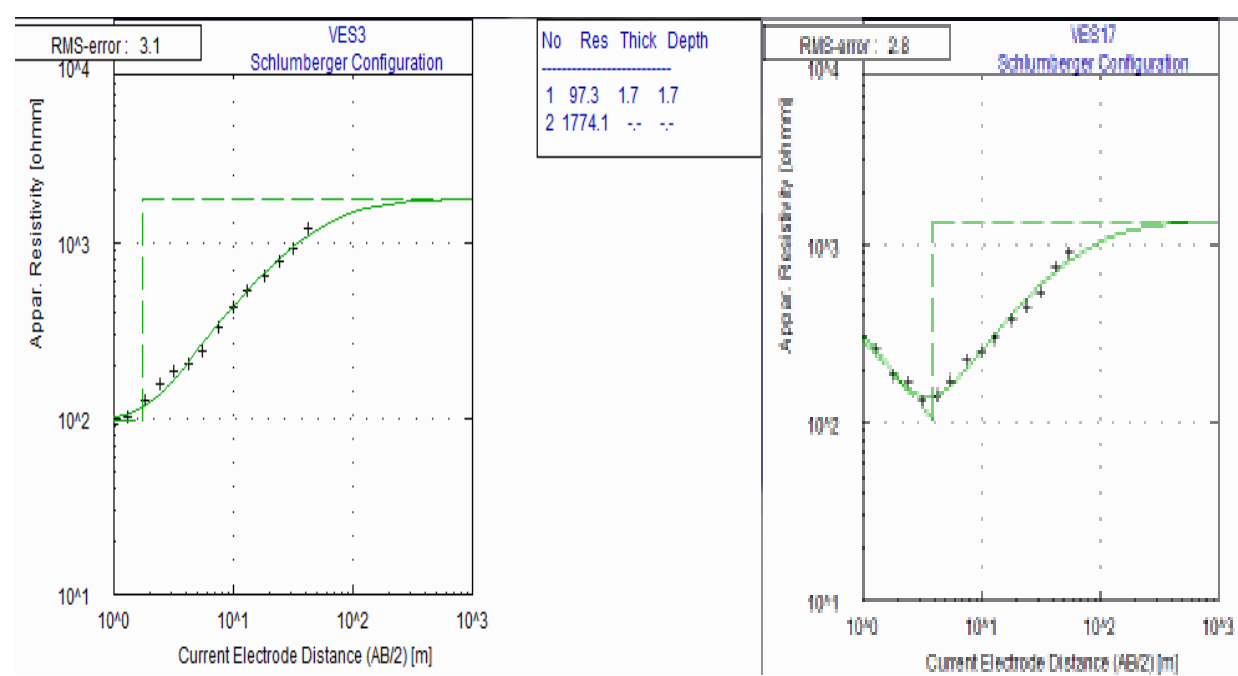

\begin{tabular}{|llll|}
\hline No & Ras & This Deth \\
\hline 1 & 493.8 & 0.7 & 0.7 \\
2 & 104.1 & 3.3 & 30 \\
3 & 1377.3 & $\ddots$ & $\ddots$ \\
\hline
\end{tabular}
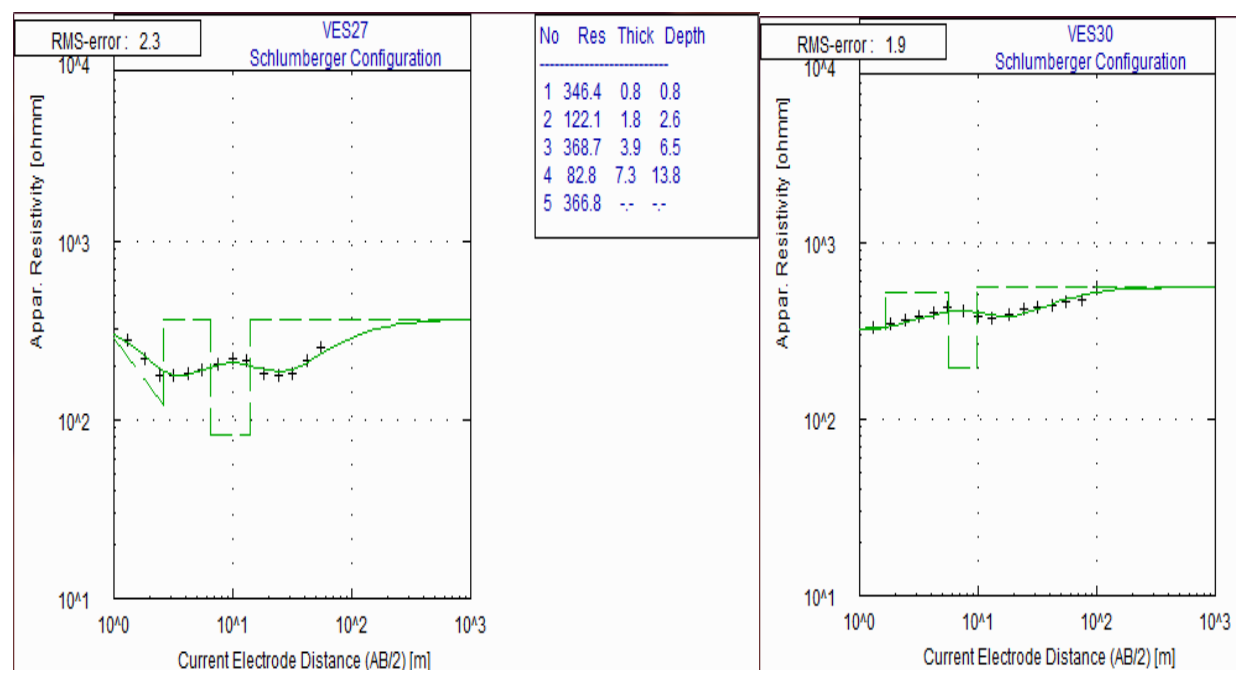

No Res Thick Depth

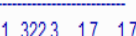

$2520.9 \quad 4.0 \quad 5.6$

$\begin{array}{llll}3 & 193.4 & 4.1 & 9.7\end{array}$

$4560.0 \quad \because \cdot$

Figures 4: Typical VES curves obtained in the study area 
Table 1: Summary of Geo-electrical parameter and Dar-zarrouk parameters of the VES curves

\begin{tabular}{|c|c|c|c|c|c|c|c|c|c|c|c|c|c|c|}
\hline \multirow[t]{2}{*}{$\begin{array}{l}\text { VES } \\
\text { No }\end{array}$} & \multicolumn{5}{|c|}{ Resistivity $(\Omega m)$} & \multicolumn{4}{|c|}{ Layer Thickness (m) } & \multirow[t]{2}{*}{$\begin{array}{l}\text { Resistivity } \\
\text { Contrast }\end{array}$} & \multirow{2}{*}{$\begin{array}{l}\text { Reflection } \\
\text { Coefficient }\end{array}$} & \multirow{2}{*}{$\begin{array}{l}\text { Longitudinal } \\
\text { Conductance } S \text { (mho) }\end{array}$} & \multirow{2}{*}{$\begin{array}{l}\text { Transverse } \\
\text { Resistance } T\left(\Omega \mathrm{m}^{2}\right)\end{array}$} & \multirow{2}{*}{$\begin{array}{l}\text { Electrical } \\
\text { Anisotropy } \lambda\end{array}$} \\
\hline & pi & pii & piii & piv & $\rho v$ & hi & hii & hiii & hiv & & & & & \\
\hline 1 & 156 & 589 & 60 & 1387 & & 0.5 & 1.2 & 4.5 & & 23.12 & 0.92 & 0.080242 & 1054.8 & 1.5 \\
\hline 2 & 912 & 114 & 1335 & & & 0.8 & 2.7 & & & 11.71 & 0.84 & 0.024561 & 1037.4 & 1.4 \\
\hline 3 & 97 & 1774 & & & & 1.7 & & & & 18.29 & 0.9 & 0.017526 & 164.9 & 1.0 \\
\hline 4 & 241 & 86 & 823 & & & 1.3 & 3.6 & & & 9.57 & 0.81 & 0.047255 & 622.9 & 1.1 \\
\hline 5 & 816 & 145 & 690 & & & 1.3 & 7.9 & & & 4.76 & 0.65 & 0.056076 & 2206.3 & 1.2 \\
\hline 6 & 136 & 1775 & & & & 1.7 & & & & 13.05 & 0.86 & 0.012500 & 231.2 & 1.0 \\
\hline 7 & 126 & 972 & & & & 4.5 & & & & 7.71 & 0.77 & 0.035714 & 567.0 & 1.0 \\
\hline 8 & 306 & 86 & 2569 & & & 0.9 & 2.5 & & & 29.87 & 0.94 & 0.032011 & 490.4 & 1.2 \\
\hline 9 & 82 & 4584 & & & & 2.4 & & & & 55.90 & 0.96 & 0.029268 & 196.8 & 1.0 \\
\hline 10 & 370 & 137 & 3231 & & & 1.8 & 3.8 & & & 23.58 & 0.92 & 0.032602 & 1186.6 & 1.1 \\
\hline 11 & 516 & 142 & 1333 & & & 0.5 & 4.1 & & & 9.39 & 0.81 & 0.029842 & 840.2 & 1.1 \\
\hline 12 & 539 & 123 & 645 & & & 0.5 & 1.6 & & & 5.24 & 0.68 & 0.013936 & 466.3 & 1.2 \\
\hline 13 & 107 & 396 & 109 & 383 & & 1.2 & 4.8 & 9.9 & & 3.51 & 0.56 & 0.114162 & 3108.3 & 1.2 \\
\hline 14 & 80 & 24 & 209 & & & 2.4 & 9 & & & 8.71 & 0.79 & 0.405000 & 408.0 & 1.1 \\
\hline 15 & 759 & 402 & 677 & & & 1.6 & 19.2 & & & 1.68 & 0.25 & 0.049869 & 8932.8 & 1.0 \\
\hline 16 & 337 & 136 & 2367 & & & 0.9 & 1.8 & & & 17.40 & 0.89 & 0.015906 & 548.1 & 1.1 \\
\hline 17 & 404 & 104 & 1377 & & & 0.7 & 3.3 & & & 13.24 & 0.86 & 0.033463 & 626.0 & 1.1 \\
\hline 18 & 396 & 53 & 6968 & & & 0.8 & 1.9 & & & 131.47 & 0.98 & 0.037869 & 417.5 & 1.5 \\
\hline 19 & 231 & 4603 & & & & 1.6 & & & & 19.93 & 0.9 & 0.006926 & 369.6 & 1.0 \\
\hline 20 & 206 & 14 & 586 & & & 0.9 & 6.7 & & & 41.86 & 0.95 & 0.482940 & 279.2 & 1.5 \\
\hline 21 & 521 & 120 & 598 & & & 0.8 & 5.1 & & & 4.98 & 0.67 & 0.044036 & 1028.8 & 1.1 \\
\hline 22 & 220 & 87 & 365 & & & 2.2 & 26 & & & 4.20 & 0.62 & 0.308851 & 2746.0 & 1.0 \\
\hline 23 & 311 & 70 & 4014 & & & 1.6 & 4.9 & & & 57.34 & 0.97 & 0.075145 & 840.6 & 1.2 \\
\hline 24 & 85 & 319 & & & & 2.1 & & & & 3.75 & 0.58 & 0.024706 & 178.5 & 1.0 \\
\hline 25 & 48 & 163 & & & & 5.6 & & & & 3.40 & 0.55 & 0.116667 & 268.8 & 1.0 \\
\hline
\end{tabular}


GEOELECTRICAL EXPLORATION FOR GROUNDWATER IN CRYSTALLINE BASEMENT ROCKS

\section{1}

\begin{tabular}{|c|c|c|c|c|c|c|c|c|c|c|c|c|c|c|}
\hline 26 & 79 & 66 & 257 & & & 2.2 & 4.8 & & & 3.89 & 0.59 & 0.100575 & 490.6 & 1.0 \\
\hline 27 & 347 & 122 & 369 & 84 & 367 & 0.8 & 1.8 & 3.9 & 7.3 & 4.37 & 0.62 & 0.114533 & 2027.6 & 1.1 \\
\hline 28 & 273 & 373 & 160 & 2888 & & 1.4 & 3.5 & 2.9 & & 18.05 & 0.89 & 0.032637 & 2151.7 & 1.1 \\
\hline 29 & 105 & 543 & & & & 6.8 & & & & 5.17 & 0.68 & 0.064762 & 714.0 & 1.0 \\
\hline 30 & 322 & 521 & 193 & 560 & & 1.7 & 4 & 4.1 & & 2.90 & 0.48 & 0.034201 & 3422.7 & 1.1 \\
\hline 31 & 68 & 18 & 296 & & & 0.6 & 4.7 & & & 16.44 & 0.88 & 0.269935 & 125.4 & 1.1 \\
\hline 32 & 91 & 35 & 301 & & & 2 & 11.5 & & & 8.60 & 0.79 & 0.350549 & 584.5 & 1.1 \\
\hline 33 & 92 & 27 & 275 & & & 1.4 & 8 & & & 10.19 & 0.82 & 0.311514 & 344.8 & 1.1 \\
\hline
\end{tabular}




\section{Aquifer Unit (Weathered Layer) Resistivity}

The resistivity values obtained from the investigated area ranges from 14 to $400 \Omega \mathrm{m}$ with average resistivity of $106 \Omega \mathrm{m}$. Figure 5 shows the variation in aquifer unit (weathered layer) resistivity across the study area. The rock type, climatic conditions and clayey contents always influence the electrical resistivity of the aquifer unit resistivity. The resistivity values obtained from the investigated area indicates that clayey soil, sandy clay and clayey sand are the material composition of the weathered basement. It was observed on the map that VES stations that falls within the layer resistivity values less than $100 \Omega \mathrm{m}$ could have higher groundwater potential because the basement has weathered into clay or sandy clay layer which allow percolation and storage. The presence of clay within the regolith will reduced the resistivity of the weathered layer less than $100 \Omega \mathrm{m}$ and consequently, decreases the permeability and thereby lower the aquifer potential (Carruthers and Smith, 1992; Olayinkaet al., 1997). It should be noted that weathered layer resistivity alone cannot be used to infer groundwater potential, other factors (Overburden thickness, basement resistivity, bedrock relief and reflection coefficient) needs to be considered. The eastern and northwestern part of the study area is characterized by low resistivity weathered basement and this with other geoelectric parameters could be pointer to good groundwater yield.

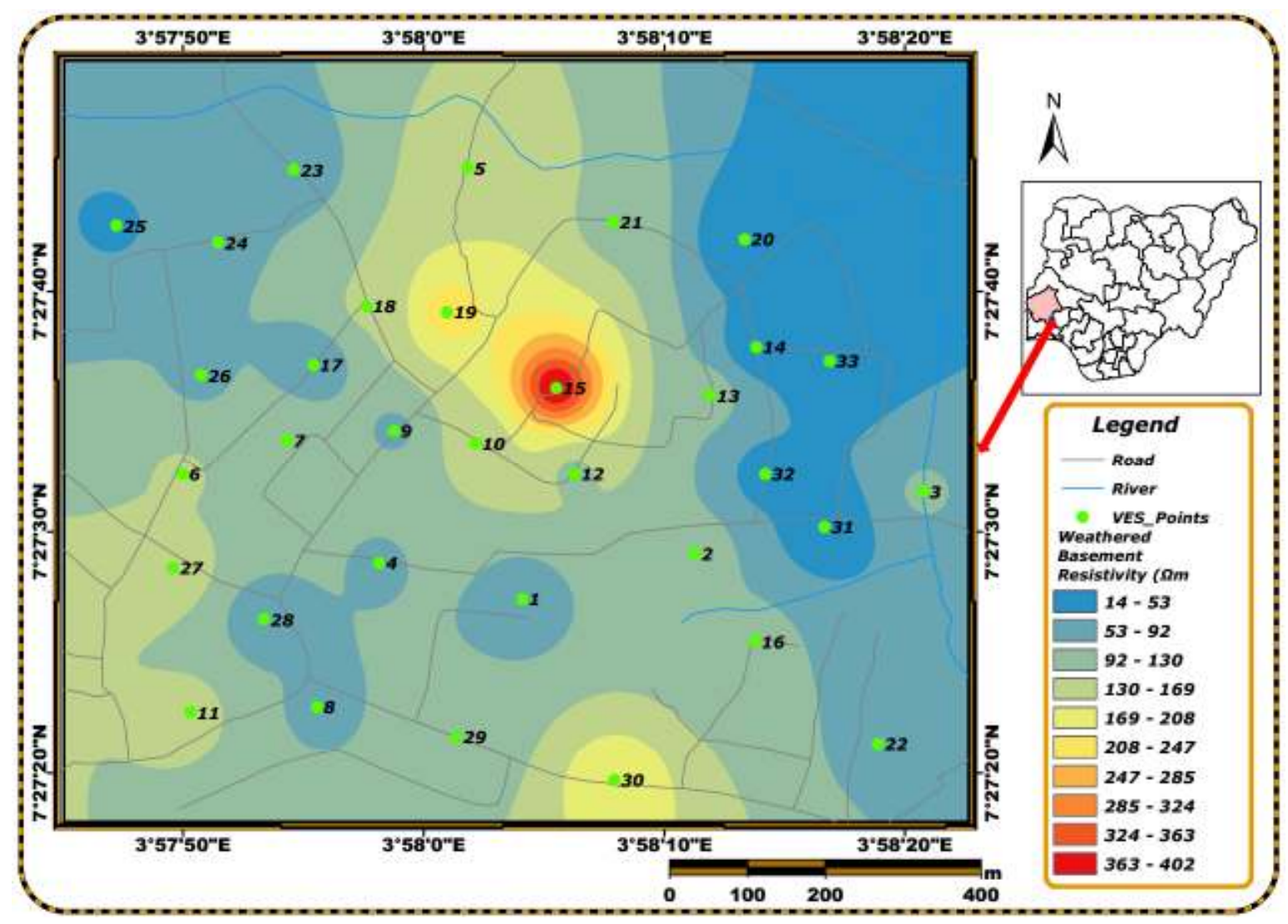

Figure 5: Aquifer unit (Weathered basement) resistivity map of Gbongudu community, Ibadan

\section{Aquifer Unit (Weathered Layer) Thickness}

The aquifer unit/weathered layer lies between the topsoil/lateritic clay and the basement rock. The thickness of the aquifer unit/weathered layer ranges between 1.6 to $26 \mathrm{~m}$ with average thickness of $6.3 \mathrm{~m}$. Figure 6 show the variation in aquifer unit/weathered basement thickness across the study area. Generally, the area is characterized by less than average thick aquifer unit and is dominated by aquifer unit thickness of less than $8 \mathrm{~m}$ which represent more than $70 \%$ of the study area. Thick aquifer unit which is $20 \mathrm{~m}$ and above is found in the southeastern part of the study area while average thickness which is between 10 to $19 \mathrm{~m}$ is found at the central part of the area and the rest part of the area is dominated by less than average thick aquifer unit. The aquifer unit shows the degree of weathering that has affected the basement around the area. The basement around the study area has not really been affected by weathering agent using the weathered basement thickness as a yardstick. 


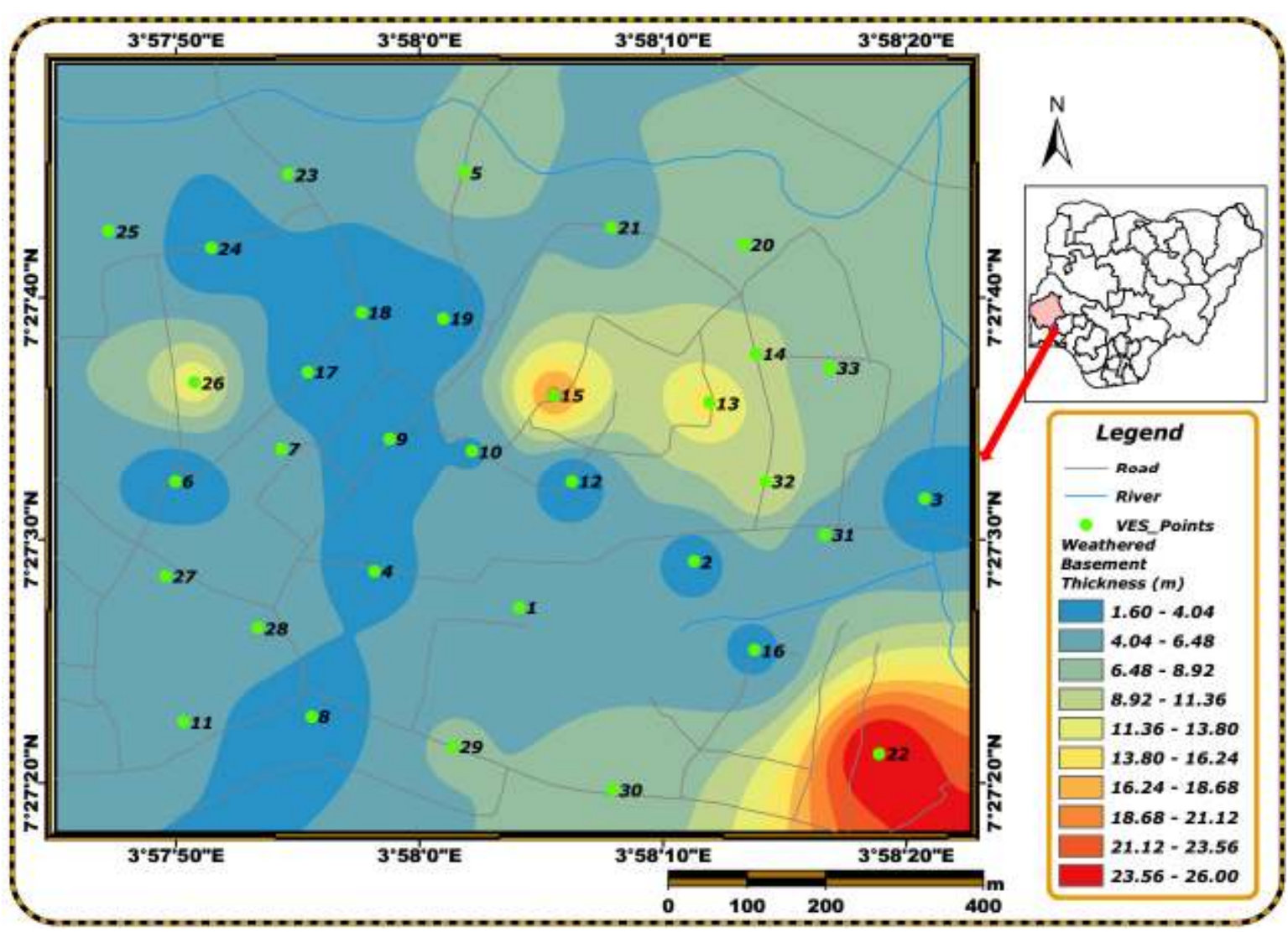

Figure 6: Aquifer unit (Weathered layer) thickness map of Gbongudu community, Ibadan

\section{Overburden Thickness}

Overburden thickness comprises the topsoil, lateritic clay, and weathered basement. Figure 7 show the variation in overburden thickness across the area investigated and it varies from 1.6 to $28.2 \mathrm{~m}$ with average thickness of about $7.2 \mathrm{~m}$. For good groundwater yield in a well, Olayinkaet al, 1997 suggested $20-30 \mathrm{~m}$ overburden thickness while Olorunfemi and Okhue, 1992 and Oladapoet al., 2004 gave $25 \mathrm{~m}$ as the thickness of overburden that is viable for groundwater abstraction. The average thickness of overburden in the investigated area is $7.2 \mathrm{~m}$ which is far less than the suggested average thickness in literatures. It is evident from the result that more than $80 \%$ of the area is less than the value suggested and the only area that meets the value is seen at the southeastern part of the study area. The result suggested that groundwater prospect around the area is very low. 


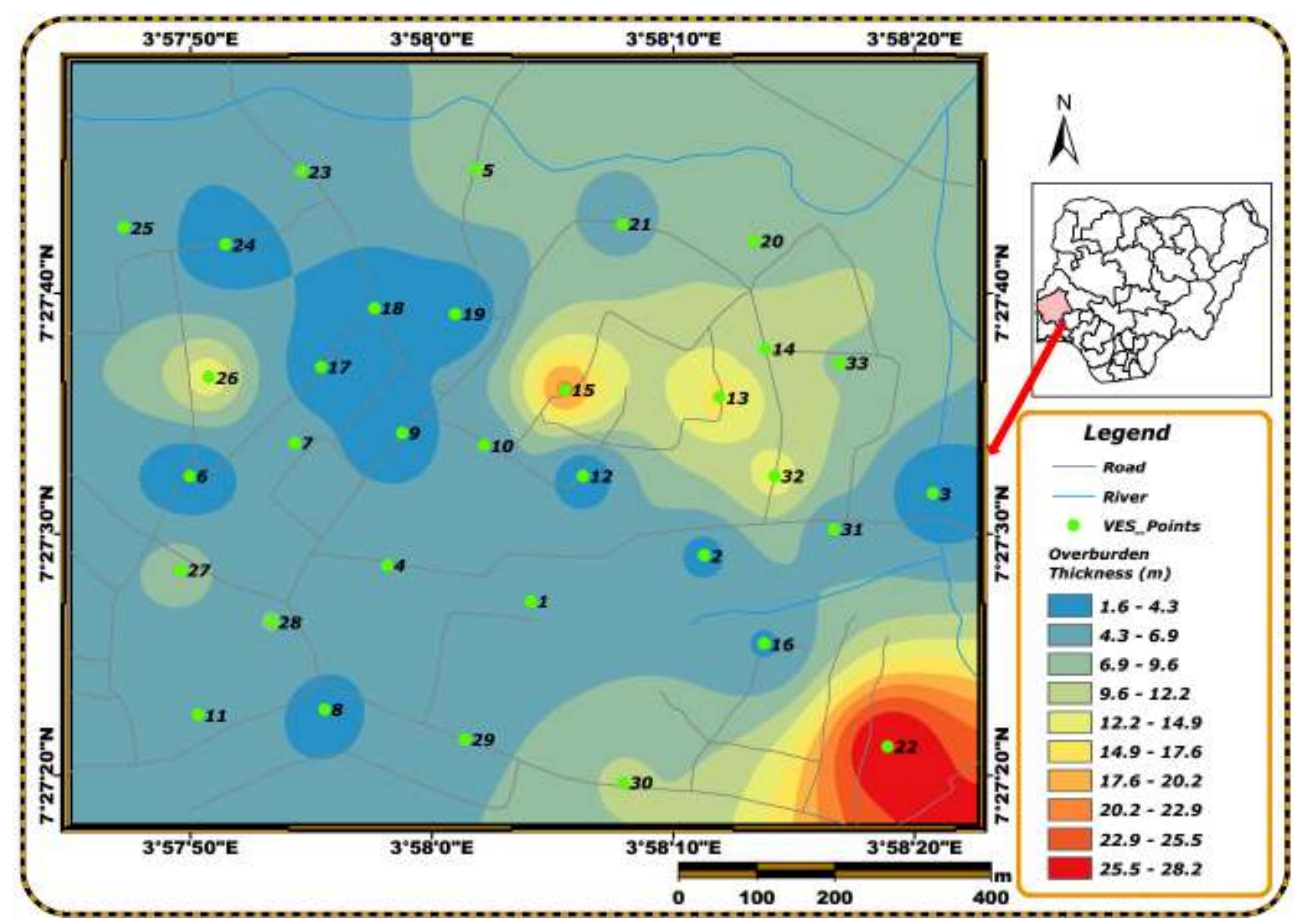

Figure 7: Overburden thickness map of Gbongudu community, Ibadan

\section{Basement Resistivity}

Figure 8 shows variation in basement resistivity across the study area which ranges from 163 to $6968 \Omega \mathrm{m}$ with average resistivity of about $1492 \Omega \mathrm{m}$. Geologically, the observed variability in the basement resistivity is as a result unpredictable and inconsistent basement aquifer which results from unevenness in weathering of basement rocks. Also, as suggested by Oladapoet al., 2004, that the difference in mineralogy and presence of different bedrock structures could be attributed to the observed variation in bedrock resistivity within the area investigated. Groundwater yield is enhanced by the presence of fractures within the basement rock which could probably be because of the relatively high permeability. Based on Olayinkaet al., 1997 and Oyedele and Olayinka (2012), classification of aquifer potential as a function of the basement rock, the basement rock can be classified as high fractured permeability as a result of weathering with resistivity less than $750 \Omega \mathrm{m}$ which can be seen in the northeastern and the southwestern part of the area investigated which is an indication of good aquifer potential. Also, basement resistivity value from 750 to $1500 \Omega \mathrm{m}$ is classified as medium aquifer potential which has reduced influence of weathering on it and can be seen in the southwestern and southeastern portion of the area investigated while basement resistivity of between 1501 to $3000 \Omega \mathrm{m}$ is classified as low aquifer potential as a result of low effect of weathering with low aquifer potential which occupy the southeastern and part of eastern portion of the area investigated. Resistivity above $3000 \Omega \mathrm{m}$ is classified as negligible aquifer potential with little or no weathering of the basement rock which can be seen at the central and part of the northern area of the study location. 


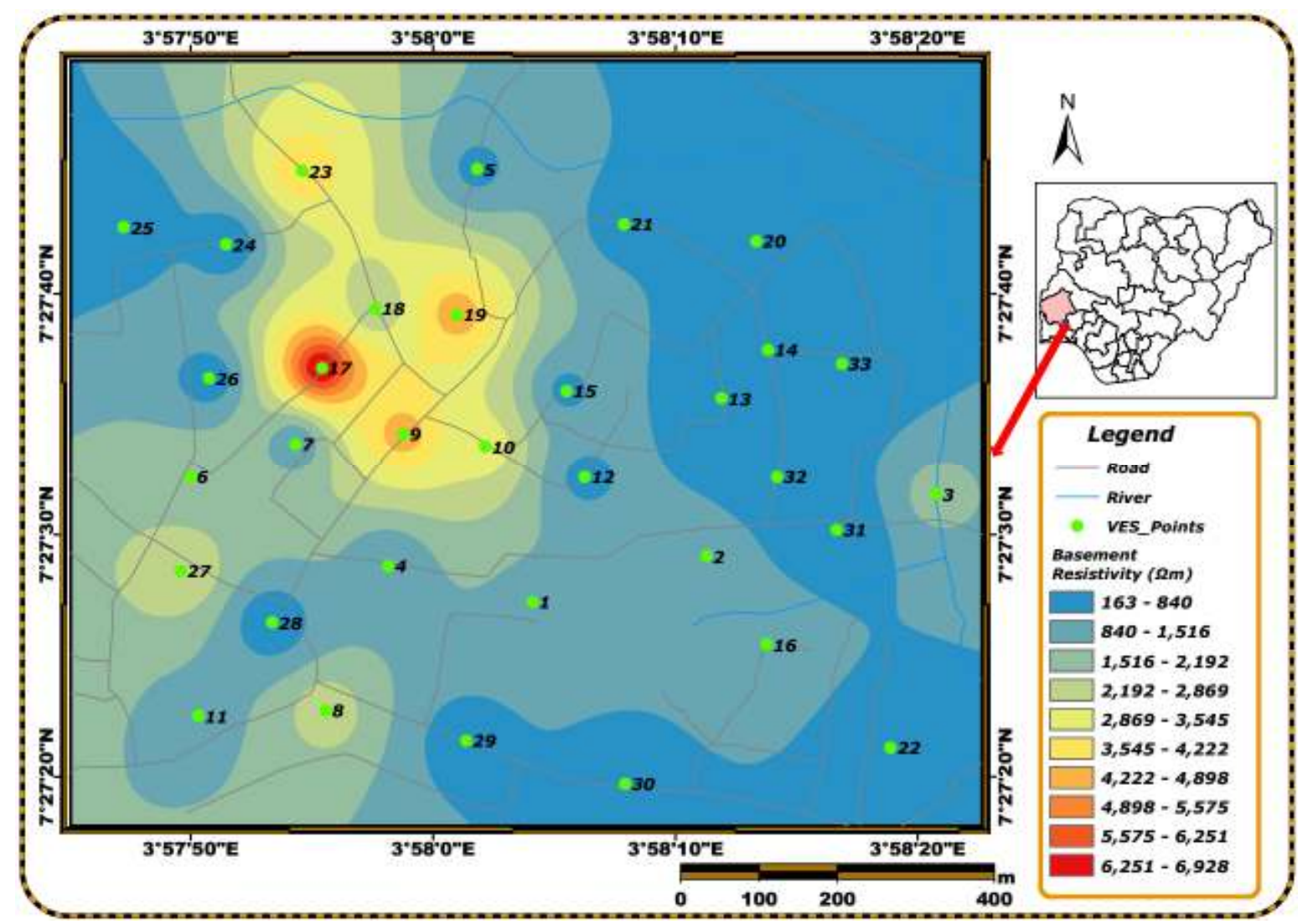

Figure 8: Basement resistivity map of Gbongudu community, Ibadan

\section{Basement Topography}

Figure 9 shows the basement topography map of the study area which display the bedrock elevation morphology at each VES point. It helps to predict the area suspected to have good groundwater prospect. The importance of basement topography hydrogeologically has been identified by various authors which include Dan-Hassan and Olorunfemi, 1991; Bala and lke, 2001. The best zones of groundwater prospect can be predicted from the basement relief map, this is possible because area with basement topographic depression (basement trough) and corresponds with thick overburden and low basement resistivity can be predicted to have good groundwater prospect on the other hand, area with basement topographic ridges and corresponds with thin overburden and high basement resistivity can be said to have poor groundwater prospect. The basement depression is noticed in the eastern part of the area investigated which suggest that the overburden is thick around this area. Other part of the area are occupied by basement which means that the overburden is shallow and any infiltration from the run off to the basement will flow to the location where basement depression is present and it will serve as groundwater storage zone. 


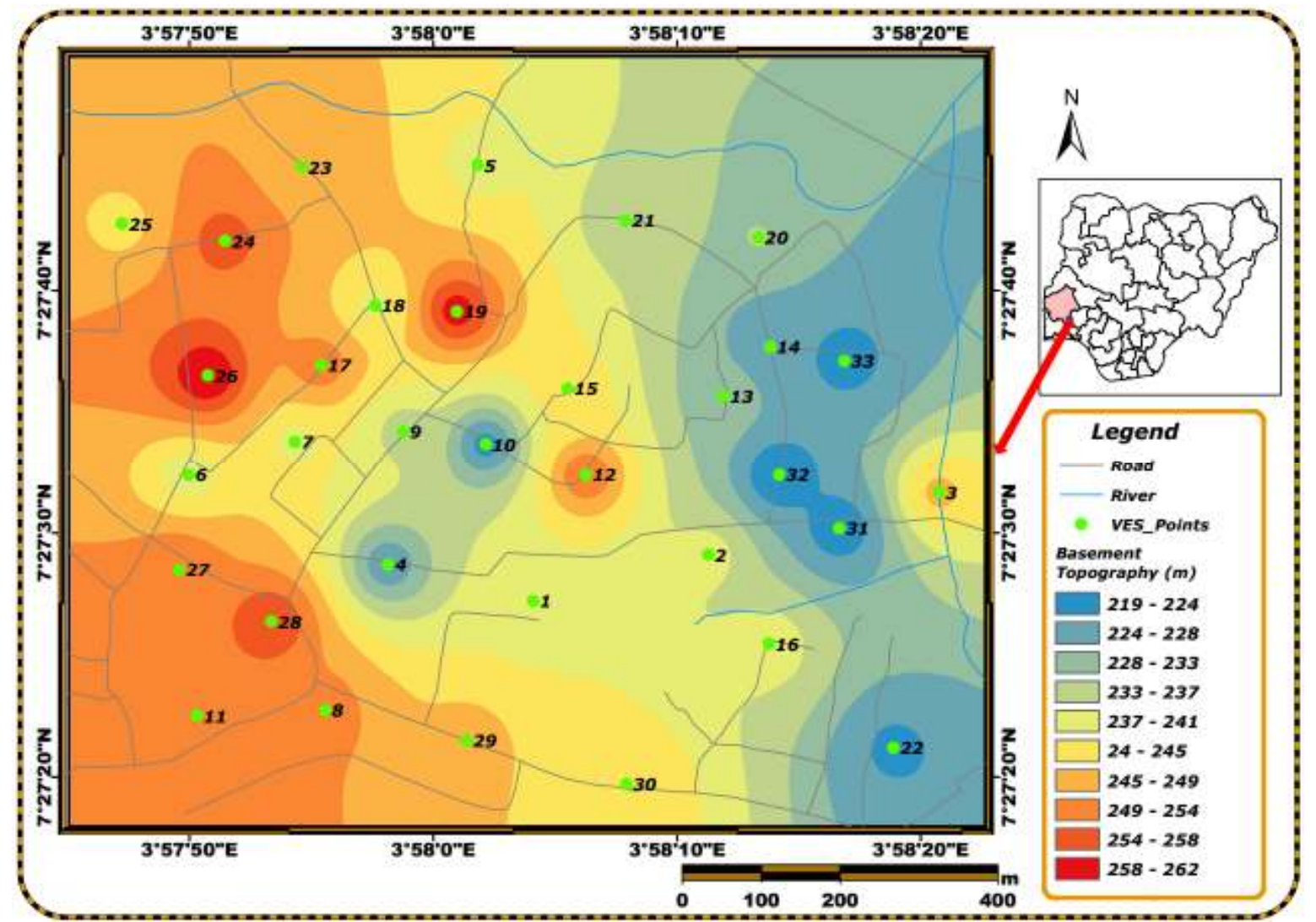

Figure 9: Basement topography map of Gbongudu community, Ibadan

\section{Reflection Coefficient and Resistivity Contrast of the Basement rock}

The reflection coefficient and resistivity contrast at the interface of fresh bedrock provide information about the about the degree of freshness or fracturing of basement rock. Olayinka, (1996)proposed that when the reflection coefficient value of VES point is increasing towards maximum value 1 , and the resistivity contrast is greater than 19, the basement is becoming fresh. The reflection coefficient and the resistivity contrast need to be considered by interpreter in delineating aquiferous zone when using basement resistivity. Any location where the reflection coefficient is less than 0.75 and the resistivity contrast is less than 19 and also, the overburden thickness is greater $25 \mathrm{~m}$, such location can be considered as good aquiferous zone. The reflection coefficient map (Fig. 10) shows the distribution of reflection coefficient across the study area, it can be observed from the map that the eastern, part of the central to the northern and part of the southwestern part have reflection coefficient greater than 0.75 which may not be good for groundwater prospecting. Also, figure 11 shows the resistivity contrast map and it can be observed that the southeastern and part of the northern part of the study area has resistivity contrast less than 19 while the rest has above 19 . 


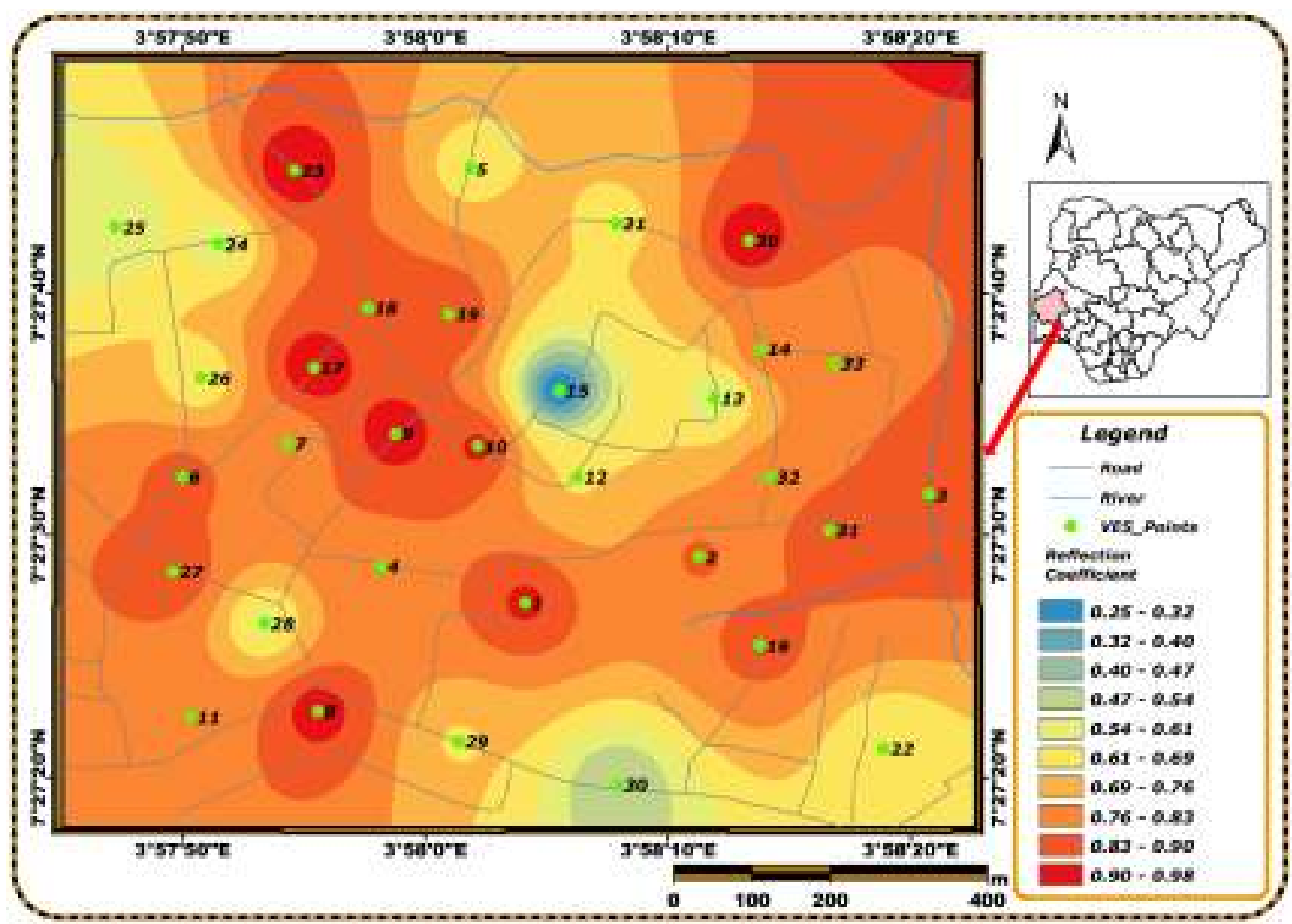

Figure 10: Reflection coefficient map of Gbongudu community, Ibadan

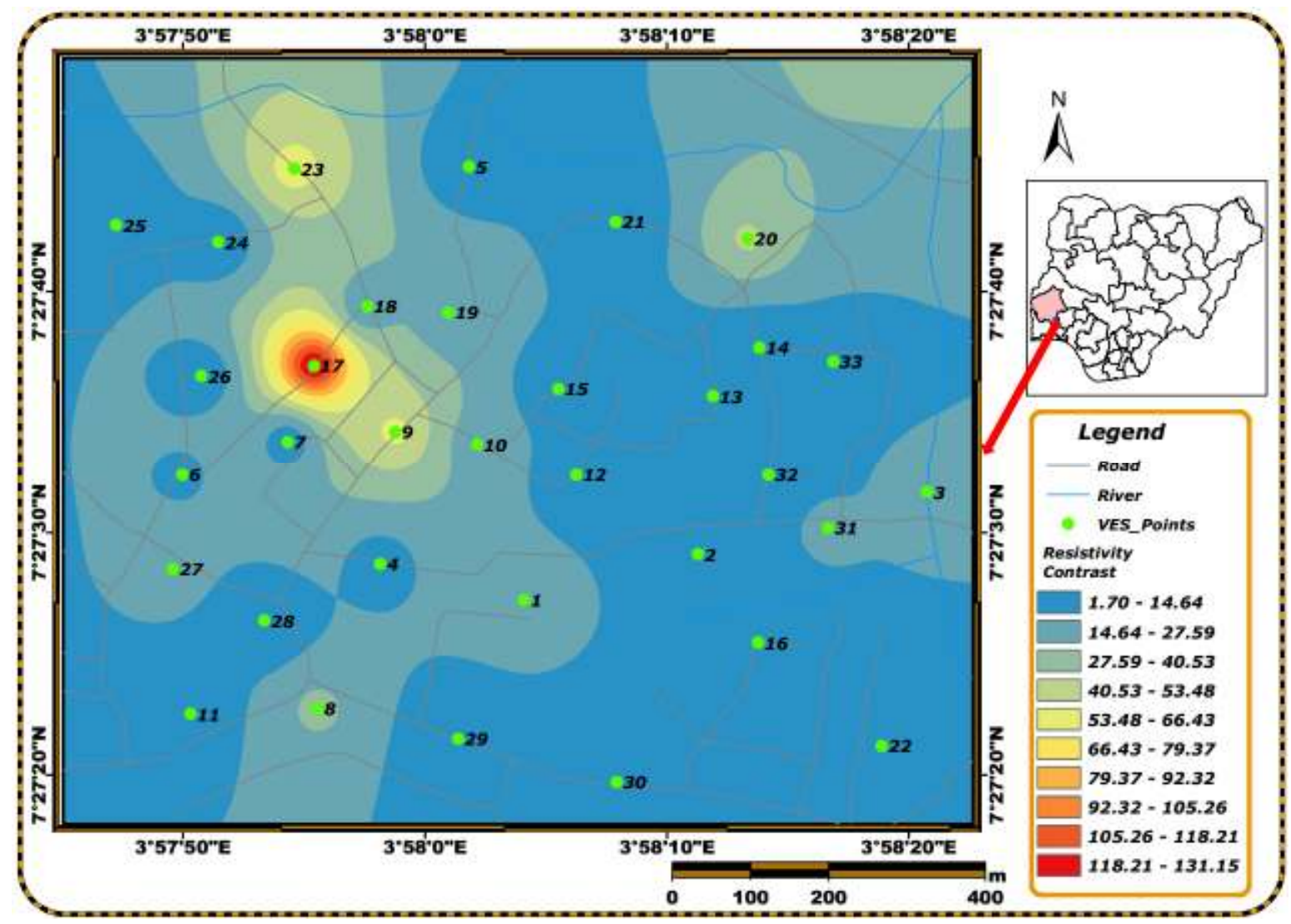

Figure 11: Resistivity contrast map of Gbongudu community, Ibadan 


\section{Total Longitudinal Conductance}

The total longitudinal conductance is also one of the Dar-Zarrouk parameter used to define target areas of groundwater potential. Figure 12 shows the variation in the longitudinal conductance across the area investigated which ranges from $0.006926 \Omega^{-1}$ to 0.48294 $\Omega^{-1}$ with average of $0.10321 \Omega^{-1}$. The variation observed in unit longitudinal conductance from one VES point to another is used qualitatively to note the changes in total thickness of low resistivity materials found within the overburden. Increase in the value of longitudinal conductance may correspond to increase in clay content and thus, a reduction in transmissivity Khalil, (2009). The clay overburden which gives relatively high longitudinal conductance protects the underlying aquifer. Based on Oladapoet al., 2004 and Abiolaet al., (2009) classification of longitudinal conductance as a function of aquifer protection of overburden to groundwater zone, the protective capacity of the overburden of longitudinal conductance less than 0.1 can be classified as poor which can be seen on the southwestern to the central part of the mapped area. Then longitudinal conductance of 0.1 to 0.19 is classified as having weak protective capacity which can be seen on the southwestern part of the area investigated while 0.2 to 0.69 is classified as having moderate aquifer protective capacity which can be seen to cover most of the eastern part of the area mapped.

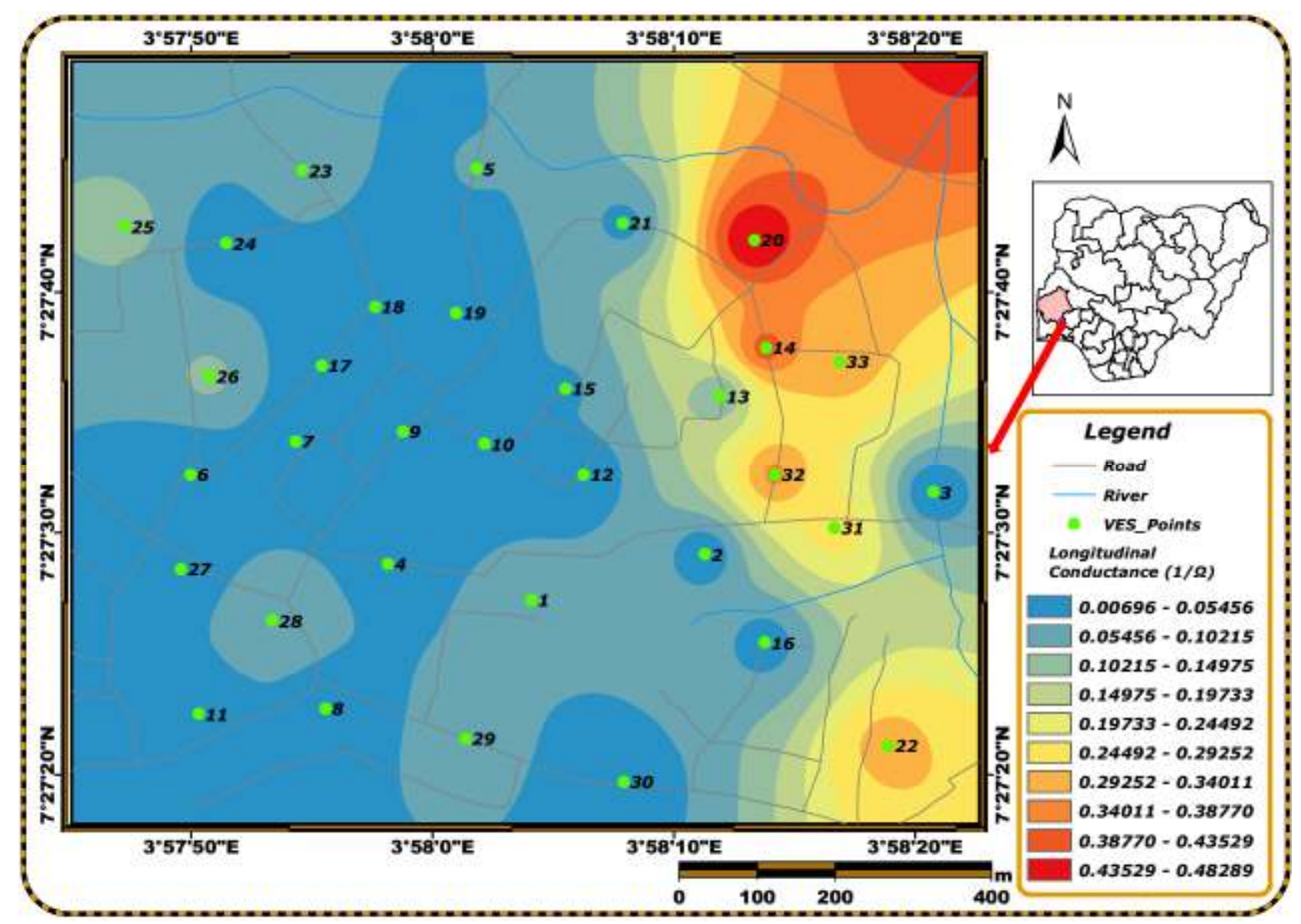

Figure 12: Total longitudinal conductance map of Gbongudu community, Ibadan

\section{Total Transverse Resistance}

The total transverse resistance to the top of basement has direct relationship with transmissivity and the highest transverse resistance value most likely reflects the highest transmissivity values of the aquiferous zone(Braga et al., 2006). Figure 13 shows the variation in the total transverse resistance of the area mapped and it ranges from 125 to $8933 \Omega \mathrm{m}^{2}$ with average of $1172 \Omega \mathrm{m}^{2}$. The total transverse resistance can be classified as; less than $400 \Omega \mathrm{m}^{2}$ to be poor with negligible transmissivity, then transverse resistance of between 400 to $1000 \Omega \mathrm{m}^{2}$ is said to be weak, while 1000 to $2000 \Omega \mathrm{m}^{2}$ is said to be moderate with moderate transmissivity and above $2000 \Omega \mathrm{m}^{2}$ is very good with good aquifer transmissivity. From the map generated for the total transverse resistance it can be observed that more than $70 \%$ of the area investigated has poor to weak transmissivity based on their total transverse resistance value. The central part of the area has good transmissivity because of the high value of total transverse resistance while the southeastern part has moderate transmissivity as observed from the value of the total transverse resistance. 


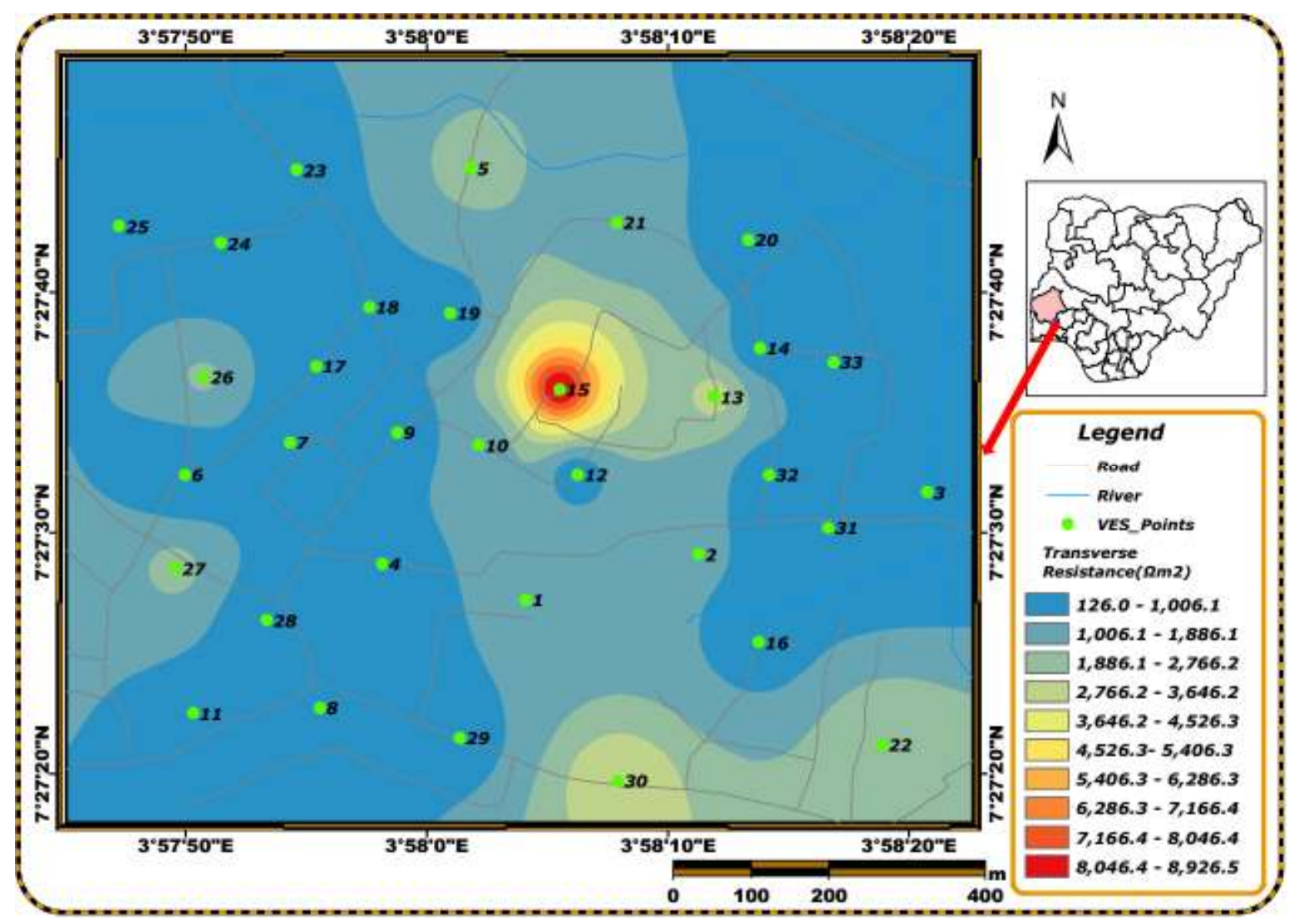

Figure 13: Total transverse resistance map of Gbongudu community, Ibadan

\section{Electrical Anisotropy/Coefficient of Anisotropy}

Figure 14 show the map of coefficient of anisotropy to the top of the bedrock which ranges from 1.00 to 1.52 with average of 1.13. The mean coefficient of anisotropy for igneous and metamorphic rocks of the Basement Complex of Southwestern Nigeria was given by Olorunfemiet al., 1991 to be 2.12 and 1.56 respectively. The value obtained for this investigation showed that the rock unit underlying the area is metamorphic rock which can be confirmed from the geologic map. Coefficient of anisotropy of resistivity in rocks are either caused by orientation of elongated grains or by layering with different resistivity value and can also be as result of rock fracturing, metamorphism or disseminated ore grains in the rocks (Habberjam, 1972; Watson and Baker, 1999). Olorunfemi and Olorunniwo, 1985; Olorunfemiet al., 1991 and Olorunfemi and Okhue, 1992 observed that the electrical anisotropy has a linear relationship with groundwater yield i.e increase in electrical anisotropy leads to increase in groundwater yield. based on linear relationship inference between coefficient of anisotropy and groundwater yield It can be observed on the map of the study area that the northeastern and part of the southern area of the map have high value of electrical anisotropy which in turn show that the area may have good groundwater yield. 


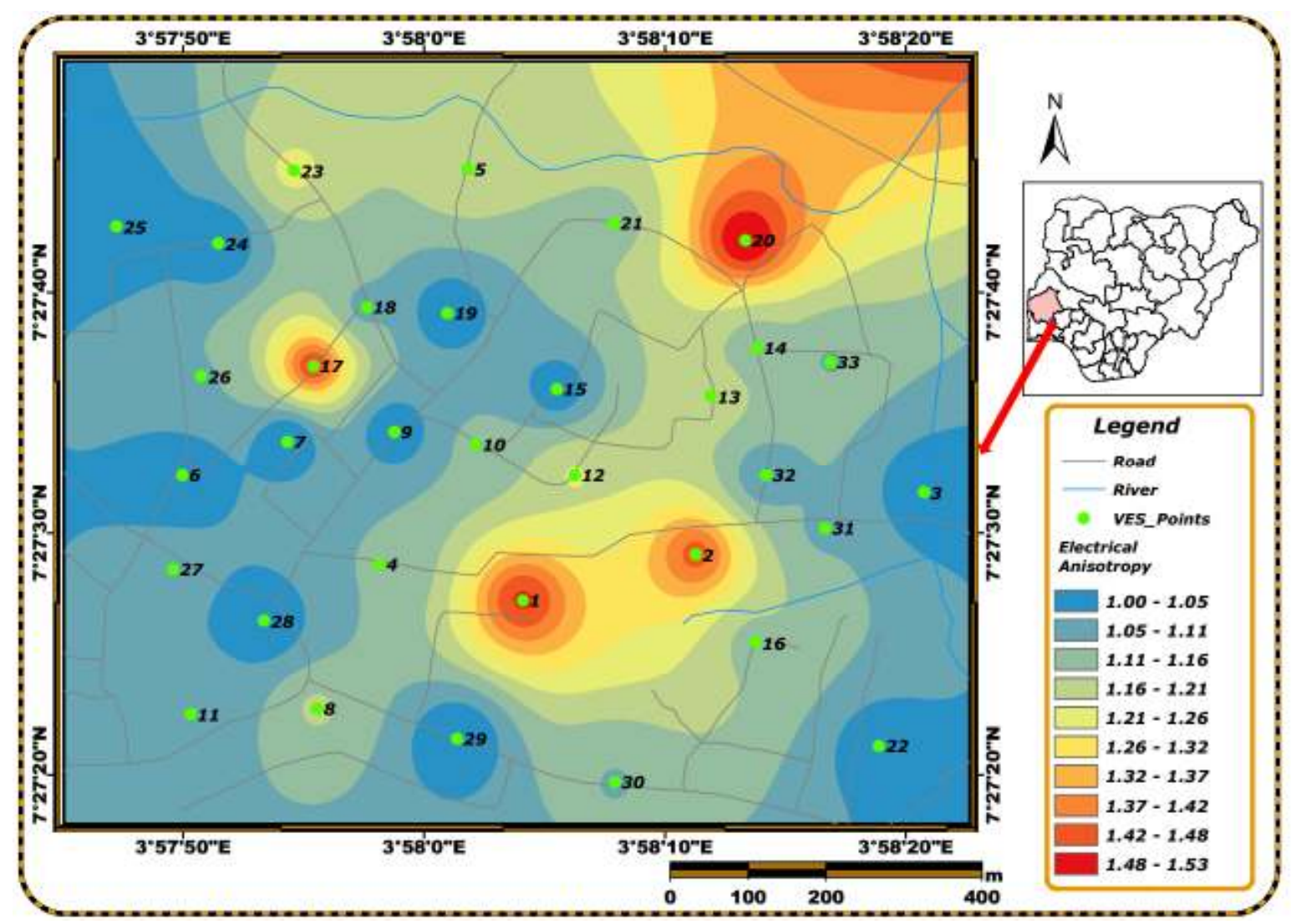

Figure 14: Electrical anisotropy/coefficient of anisotropy map of Gbongudu community, Ibadan

\section{Groundwater Potential Assessment}

The groundwater potential of Gbongudu community in Ibadan was assessed by integration of results of aquifer unit (weathered basement) resistivity, overburden thickness, basement resistivity, basement topography, reflection coefficient, longitudinal conductance, transverse resistance and electrical anisotropy to generate groundwater potential map (Fig.15). Olayinka, et al., 2004 and Barker, et al., 1992 suggested that good groundwater potential zone must have overburden greater than $10 \mathrm{~m}$, the basement must show an indication of fracture from the basement resistivity value which should be less or equal to $800 \Omega \mathrm{m}$ and the aquifer unit (weathered basement) resistivity should be between 50 to $300 \Omega \mathrm{m}$. In addition, the zone should be classified as basement depression on basement topography map while the value of the reflection coefficient should be less than 0.75 and the coefficient of anisotropy value should be greater than 1.2 which indicate basement fracture and should have low longitudinal conductance unit which show an increase in transmissivity and high transverse resistance.

The groundwater potential map was produced from the integration of geo-electric and Dar-Zarrouk parameters and was used to evaluate the groundwater potential of the study location by categorizing it as poor, low and good aquifer potential zones. It was inferred from the groundwater potential map that part of the northwestern through part of the central area to the southwestern zone is characterized by poor aquifer potential which is considered to account for about $30 \%$ of the mapped area. Also observed on the map is that from the northeast through central to southern part of the area and part of the northwest is characterized by low groundwater potential which account for about $65 \%$ of the investigated area and lastly, the southeastern part is characterized by good aquifer potential which account for about $5 \%$ of the mapped area. 


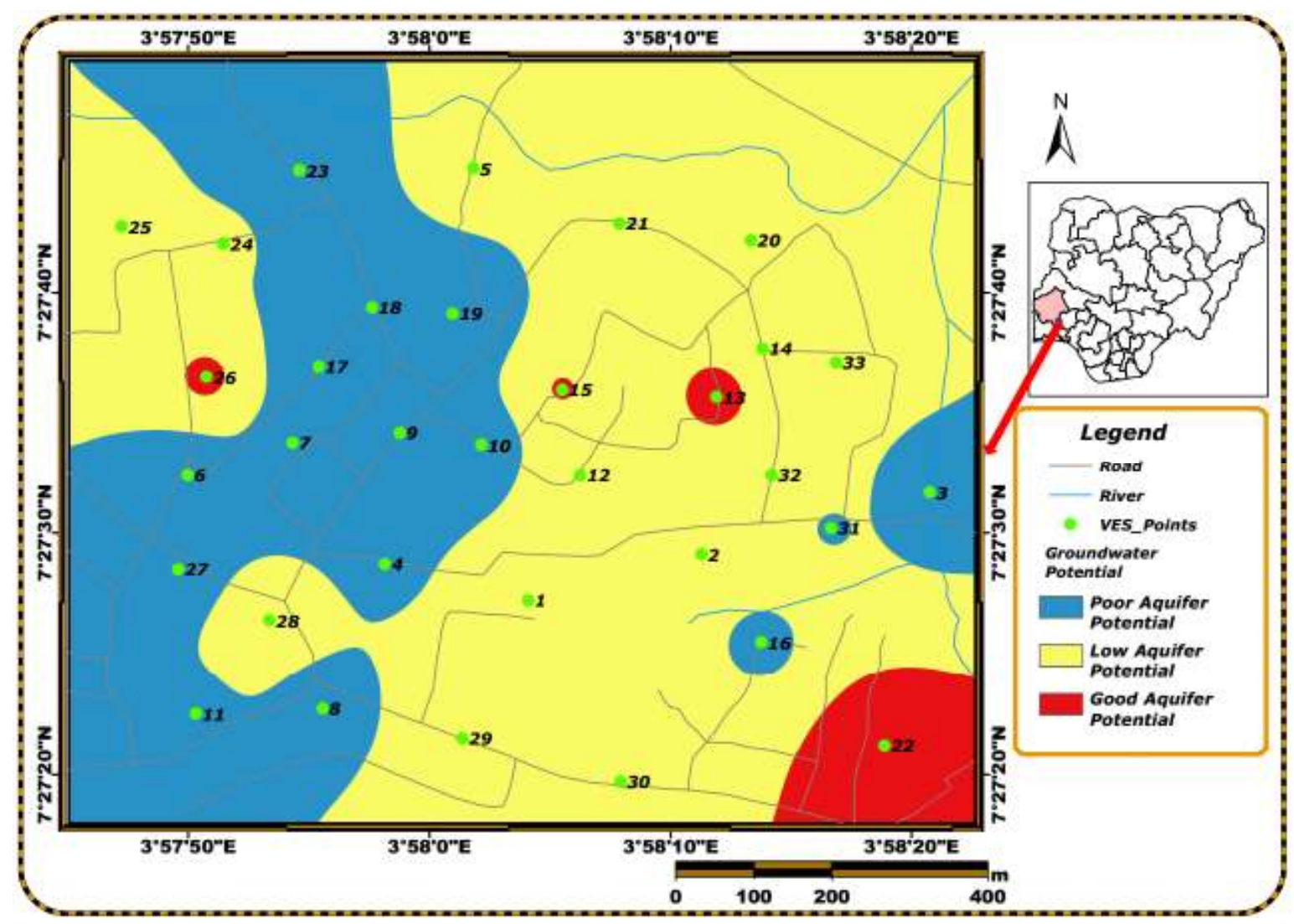

Figure 15: Groundwater potential map of Gbongudu community, Ibadan

\section{Conclusion and Recommendation}

The geo-electric layer and Dar-Zarrouk parameters of 33 VES with were analyzed for Gbongudu community in Ibadan, part of Basement Complex of Southwestern Nigeria. From the above analyses, the results show two to five geo-electric layers, namely topsoil, clayey soil, lateritic clay, weathered basement and fractured/fresh basement. From the VES data interpreted various geoelectric parameters as well as Dar-Zarrouk parameters were determined. The determined parameters were used to generate different hydro-resistivity maps such as aquifer unit (weathered basement) thickness map, aquifer unit (weathered basement) resistivity map, overburden thickness map, basement resistivity map, basement topography map, reflection coefficient map, total longitudinal conductance map, total transverse resistance map and electrical anisotropy (coefficient of anisotropy) map. The thematic maps were integrated to form a single map from which the groundwater potential map of the study area was generated. The generated groundwater potential map for the area was analyzed and used to categorize the area into poor, low and good aquifer zones. The best area for borehole location is at the southeastern part of the area. It is assumed that the results of this study will offer reliable background knowledge for an elaborate groundwater development in Gbongudu community.

\section{REFERENCES}

Abiola, O., Enikanselu, P. A. and Oladapo, M. I., 2009: Groundwater potential and aquifer protective capacity of overburden units in Ado-Ekiti, Southwestern Nigeria. International Journal of the Physical Sciences, 5(5), pp. 415-420.

Bala, A. E. and Ike, E. C., 2001: The aquifer of the crystalline basement rocks in Gusau area, northwestern Nigeria. Journal of Mining and Geology, 37 (2): 177-184.

Barker, R. D., White, C. C. and Houston, D. F., 1992: Borehole siting in an African Accelerated Drought Relief Project. Hydrogeology of crystalline basement aquifers in Africa. Geological Society of London special publication, 66, pp. 183-201.

Bear, J. and Verruijt, A., 1987: Modeling Groundwater Flow and Pollution. D. Reidel Publishing Company, Dordecht, Holland.

Braga, O. C., Filho, W. M. and Dourado, J. C., 2006: Resistivity (DC) method applied to aquifer protection studies. Brazilian Journal of Geophysics, 24(4), pp. 574-581. 
Carruthers, R. M. and Smith, I. F., 1992. The use of ground electrical survey methods for siting water supply boreholes in shallow crystalline basement terrains. In: Wright, E. P. and Burgess, W. G. (Eds), The hydrogeology of crystalline basement aquifers in Africa. Geological society of London special publication, No. 66, pp. 203-220.

Dan-Hassan, M. A. and Olorunfemi, M. O., 1999: Hydrogeophysical investigation of a basement terrain in the north central part of Kaduna State, Nigeria. Journal of Mining and Geology, Vol. 2, (35), 189-206.

Edet, A.E., Okereke, C.S., Teme, S.C., Esu, E.O., 1998: Application of remote-sensing data to groundwater exploration: a case study of the Cross River state, Southeastern Nigeria. Hydrogeol J 6:394-404 FAO, (2003): Review of world water resources by country. In: Water Reports, vol. 23, Rome, Italy.

Habberjam, G.M., 1972: The Effect of Electrical Anisotropy on Square array resistivity measurements. Geophysical prospecting. 20: 249-266.

Jaturon, K., Wiewwiwun, R. and Srilert, C., 2014: Hydrogeologic characteristics and groundwater potentiality mapping using potential surface analysis in the Huay Sai area, Phetchaburi province, Thailand. Geosci. J. 18 (1), 89-103. http://dx.doi.org/10.1007/s12303-013-0047-6

Khali, M. H., 2009: Hydrogeophysical assessment of Wdi El-Sheikh aquifer, Saint Katherine, South Sinai, Egypt. Journal of Environmental and Engineering Geophysics, 14(2), pp. 77-86.

Koefoed, O., 1979: Resistivity Soundings Measurements in Geo Sounding, Principles. Vol. 1. New York, Elsevier

Kumar, P., Gopinath, G. and Seralathan, O., 2007: Application of remote sensing and GIS for the demarcation of groundwater potential areas of a river basin in Kerala, southwest coast of India. Int. J. Remote Sens. 28, 5583-5601.

Maillet, R., 1947: The fundamental equation of electric prospecting. Geophysics 12(4):529-556

Nampak, H., Pradhan, B., Manap, M.A., 2014: Application of GIS basedndata driven evidential belief function model to predict groundwater potential zonation. J Hydrol 513:283-300

Ojo J.S. and Olorunfemi M.O., 1990: Geophysical Survey of Dam Site A Case Study J. Min. Geol. 26 (2) 201-206.

Oladapo, M. I., Mohammed, M. Z, Adeoye, O. O. and Adetola, B. A., 2004: Geoelectric investigation of the Ondo state housing corporation estate,
ljapoAkure, southwestern Nigeria, Journal of Mining and Geology, 40(1), pp. 41-48

Olayinka, A. I., 1996: Non-uniqueness in the interpretation of bedrock resistivity from sounding curves and its hydrogeological implications. Water Resources, Journal of the Nigerian Association of Hydrogeologists, 7 (1 and 2): 49-55

Olayinka, A.I., Akpan, E. J. and Magbagbeola, O. A., 1997: Geoelectric sounding for estimating aquifer potential in the crystalline basement area around shaki, southwestern Nigeria. Water Resources- Journal of NAH, Vol. 8, (1 and 2), 71-81.

Olayinka, A.I., Amidu, S.A. and Oladunjoye, M.A., 2004: Use of Electromagnetic Profiling and Resistivity Sounding for Groundwater Exploration in the Crystalline Basement Area of Igbeti, Southwestern Nigeria. Global Journal of Geological Sciences, 2, 243-253. http://dx.doi.org/10.4314/gigs.v2i2.18701

Olorunfemi, M. O. and Okhue, E. T., 1992: Hydrogeological and Geologic significance of a geoelectric survey at Ile-Ife. Nigeria Journal of Mining and Geosciences Society, 28, pp. 221229.

Olorunfemi, M. O., Olarenwaju, V. O. and Alade, O., 1991: On the electrical anisotropy and groundwater yield in a Basement Complex area of South Western Nigeria. Journal of African Earth Sciences, Vol. 12, No. 3, pp.467-472.

Olorunniwo, M. A. and Olorufemi, M. O., 1987: Geophysical investigation for groundwater in PreCambrian terrains: A case history from Ikare, southwestern Nigeria. Journal of African Earth Sciences, 6: 787-796.

Olrunfemi, M. O. and Olorunniwo, M. A., 1985: Geoelectric parameters and aquifer characteristics of some parts of southwestern Nigeria. GeologiaApplicata E, Idrogeologia, XX, part 1, pp. 99-109

Omorinola 1984. Investigation of Ground Water Potential Fractive, Acquifer and Weathering Water Resource: Geophysical Survey of Nigeria Vol. 12, 22-26.

Orellana, E. and Mooney, H. M., 1966: Master Curves for Schlumberger Arrangement, Madrid, p. 34.

Owoyemi, F.B., 1996: "A Geologic-geophysical Investigation of Rain-induced Erosional Features in Akure Metropolis", Unpublished 
M.Sc. Thesis, Federal University of Technology, Akure. $11-18$.

Oyedele, E. A. and Olayinka, A. I., 2012: Statistical evaluation of groundwater potential of Ado-Ekiti southwestern Nigeria. Transnational Journal of Science and Technology, 2(6), pp. 110-127.

Oyinloye, A. O., 2011: Geology and Geotectonic Setting of the Basement Complex Rocks in South Western Nigeria: Implications on Provenance and Evolution. Earth and Environmental Sciences, Dr. Imran Ahmad Dar (Ed.), ISBN: 978-953-307-468-9.

Singh, K. P., 2005: Nonlinear estimation of aquifer parameters from surficial resistivity measurements. Hydrology and Earth System Sciences Discussion 2:917-938

Watson, K.A. and Barker, R.D., 1999: Differentiating anisotropy and lateral effects using azimuthal resistivity offset Wenner soundings. Geophys., 64(3): 739-745.

Wright, C. P., 1992: The hydrogeology of crystalline basement aquifers in Africa. In: C. P. Wright and W. C. Burgess (eds). Hydrogeology of Crystalline Basement aquifer in Africa. Geological Society of London Special Publication No. 66 Pp. 1 - 27

Zohdy, A. A. R., 1969: The use of Schlumberger and Equatorial soundings in groundwater investigations near El Paso, Texas. Geophysics, 34, pp. $713-728$ 